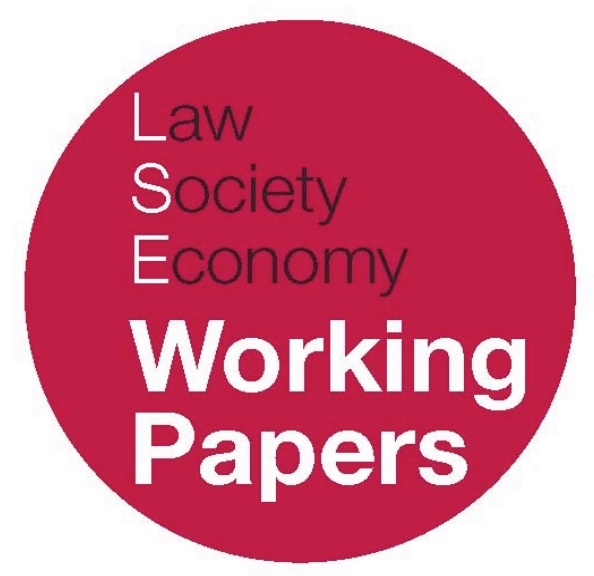

\title{
A view from inside the kitchen of the Kampala Convention: the modernisation of the international legal regime for the protection of internally displaced persons
}

\section{Chaloka Beyani}

LSE Law, Society and Economy Working Papers 17/2020

London School of Economics and Political Science

Law Department

This paper can be downloaded without charge from LSE Law, Society and Economy Working Papers at: www.lse.ac.uk/collections/law/wps/wps.htm and the Social Sciences Research Network electronic library at: $\underline{\text { https: } / / \text { ssrn.com/abstract }=3736788 .}$.

(C) Chaloka Beyani. Users may download and/or print one copy to facilitate their private study or for non-commercial research. Users may not engage in further distribution of this material or use it for any profit-making activities or any other form of commercial gain. 


\title{
A view from inside the kitchen of the Kampala Convention: the modernisation of the international legal regime for the protection of internally displaced persons
}

\author{
Chaloka Beyani*
}

\begin{abstract}
In offering a view from the kitchen in this article, the author notes the appraisal of the 10th anniversary of the Kampala Convention and argues that this Convention has modernised a somewhat soft static international legal framework relating to internally displaced persons based on the 1998 Guiding Principles on Internal Displacement and the related 2006 Protocols of the International Conference on the Great Lakes Region. A key modernising characteristic of the Kampala Convention involves its creation of a binding legal framework that goes beyond state responsibility, in establishing obligations for the African Union, international organisations, civil society, and other non-state actors (such as armed opposition groups). A host of other modernising characteristics of the Kampala Convention are suggested in this article, such as the broadening of obligations to tackle the effects of disasters and climate change, or development, on displacement. While much work remains in translating the provisions of the Kampala Convention into practice domestically, it is suggested that creating such broader obligations in line with the Kampala Convention on an international legal scale would substantively modernise the international legal regime for the protection of internally displaced persons.
\end{abstract}

* Associate Professor of International Law, London School of Economics, former United Nations Special Rapporteur on the human rights of internally displaced persons 2010-2016 (D.Pbil, Oxon 1992). 


\section{INTRODUCTION}

The African Union Convention for the Protection and Assistance of Internally Displaced Persons in Africa (the Kampala Convention) ${ }^{1}$ was adopted by the African Union on $23^{\text {rd }}$ October 2009 in Kampala, Uganda. As a treaty, the Kampala Convention is the first regional treaty of its kind applicable for the protection and assistance of internally displaced persons as well as providing for the attainment of durable solutions for them. In this regard, the Kampala Convention establishes rules expressly recognised by the state parties, whether general or particular, as a formal source of international law in line with Article 38 of the Statute of the International Court of Justice.

It entered into force on 6 ${ }^{\text {th }}$ December 2012, ${ }^{2}$ three years after its adoption, which is a record time for African Union treaties to come into force. At the time of writing, 40 of the 55 States Members of the African Union have signed the Kampala Convention, while 30 have ratified it. The signatories to the Kampala Convention would have been higher, but for the fact that the African Union required only those states that had full powers to be signatories at the adoption ceremony. States with full powers at the signing ceremony were either represented by Heads of States or Ministers of Foreign Affairs, whilst those whose representatives did not possess full powers according to the 1969 Vienna Convention on the Law of Treaties were excluded. ${ }^{3}$

In offering a view from the kitchen in this article, the author notes the appraisal of the $10^{\text {th }}$ anniversary of the Kampala Convention, and argues that from its regional domain in the context of its inception and negotiation stretching from 2005 to its adoption in 2009, the Kampala Convention has modernised a somewhat soft static international legal framework relating to internally displaced persons (based on the 1998 Guiding Principles on Internal Displacement (Guiding Principles) and the related 2006 Protocols of the International Conference on the Great Lakes Region). Its modernity is seen in the way in which it has transformed a narrow human rights centric international framework based on the Guiding Principles into a wider binding framework based on state responsibility and the responsibilities of other actors, such as the African Union, international organisations, civil society organisations, and non-state actors, particularly armed opposition groups.

This argument is buttressed by the plaudits with which the world commemorated the $10^{\text {th }}$ anniversary of the adoption of the Kampala Convention on 23rd October 2019. Marking the significance of the Kampala Convention, United Nations Secretary General Antonio Guterres noted that:

'[T] oday marks the $10^{\text {th }}$ anniversary of the adoption of the African Union Convention for the Protection and Assistance of Internally Displaced Persons in Africa. Widely known as the Kampala Convention, this seminal treaty is the first and only continentwide, legally binding instrument for the protection and assistance of internally

\footnotetext{
${ }_{1}^{1}$ Available at: https://au.int/en/treaties/african-union-convention-protection-and-assistance-internally-displacedpersons-africa

$2^{2 \text { "8th }}$ Level Dialogue on the AU Theme of the Year 2019", African Union, December 4-6 2019. Available at: https://au.int/en/newsevents/20191204/8th-high-level-dialogue-au-theme-year-2019

3 UNTS, Vol. 1155, p.331.
} 
displaced persons. The adoption of the Convention represented an important milestone in Africa's efforts to address internal displacement and demonstrated the African Union $[s i c]$ leadership role in developing standards on internal displacement. I also commend its commitment to advance the rights and well-being of people uprooted within their own countries'. ${ }^{4}$

Drawing on the inspiration of the Kampala Convention internationally, the Secretary General used the occasion of its $10^{\text {th }}$ anniversary to announce the establishment of a United Nations High-Level Panel on Internal Displacement to focus on finding solutions to internal displacement, to alleviate the suffering of millions of internally displaced persons and displacement affected populations in the world. His statement drew attention to the magnitude of internal displacement, with conflict related displacement reaching an all-time high of more than 41 million in 2018, while an additional 17 million persons had been displaced by disasters in the same year. ${ }^{5}$

Accordingly, on 3rd December 2019 the Secretary General appointed a United Nations High-Level Panel on Internal Displacement, ${ }^{6}$ inclusive of an Expert Advisory Group, 7 and mandated it to find 'concrete long-term solutions to and raising global awareness of internal displacement for Member States and the United Nations to improve their efforts to help all those affected, including both the displaced and their host communities'. ${ }^{8}$

\footnotetext{
4 "Secretary-General's statement announcing the establishment of a High-Level Panel on Internal Displacement", United Nations, October 23, 2019. Available at: https://www.un.org/sg/en/content/sg/statement/2019-1023/secretary-generals-statement-announcing-the-establishment-of-high-level-panel-internal-displacement.

5 Ibid.

${ }^{6}$ Members of the High-Level Panel are Federica Mogherini (Italy), former High Representative of the Union for Foreign Affairs and Security Policy and former Vice-President of the European Commission, Donald Kaberuka (Rwanda), Chair of the Board of the Global Fund to Fight AIDS, Tuberculosis and Malaria and former President of the African Development Bank Group as Co-Chairs; Paula Gaviria Betancur (Colombia), DirectorGeneral of Fundacion Compaz, former Presidential Counsellor on Human Rights in Colombia and former head of the Government's Victims Unit; Nasser Judeh (Jordan), member of the Senate of the Hashemite Kingdom of Jordan and a member of the UN Secretary-General's High-Level Advisory Board on Mediation, and former Minister of Foreign Affairs of Jordan; Per Heggenes (Norway), CEO of IKEA Foundation; Mitiku Kassa Gutile (Ethiopia), the Commissioner for Emergency Response in Ethiopia responsible for addressing internal displacement; Pauline Riak (South Sudan), Chair of the Board of Directors at the Sudd Institute and Deputy Vice Chancellor of the University of Juba; Sima Samar (Afghanistan), Special Envoy of the President and State Minister for Human Rights and International Affairs in Afghanistan, as well as a member of the UN Secretary-General's High-Level Advisory Board on Mediation;

7 Members of the Expert Advisory Group are Chaloka Beyani, Associate Professor of International Law at the London School of Economics (LSE) and former United Nations Special Rapporteur on the Human Rights of Internally Displaced Persons, drafter and negotiator of the Kampala Convention, and legal advisor to a range of UN entities and international organizations; Alexandra Bilak, Director of the Internal Displacement Monitoring Centre (IDMC) and served previously as Country Director and Programme Manager for several international nongovernmental organizations and research institutes in sub-Saharan Africa; Walter Kälin, Professor Emeritus of International Law at the University of Bern, Envoy of the Chair of the Platform on Disaster Displacement and former Representative of the Secretary-General on the Human Rights of Internally Displaced Persons; and Elizabeth Ferris, research professor at the Institute for the Study of International Migration at Georgetown University, and former Co-Director of the Brookings Project on Internal Displacement.

8 "Terms of Reference: Level Panel on Internal Displacement", United Nations, 2019. Available at: https://www.un.org/internal-displacement-panel/sites/www.un.org.internal-displacementpanel/files/tor of the panel.pdf
} 
Ahead of the United Nations, the African Union celebrated the $10^{\text {th }}$ anniversary of the Kampala Convention by declaring 2019 as the year of refugees, returnees, and internally displaced persons; this was a year that also commemorated the 50th anniversary of the 1969 OAU Convention Governing the Specific Aspects of Refugee Problems in Africa. ${ }^{9}$ Specifically, a High-Level event was convened by the African Union in Kampala on $4^{\text {th }}$ $6^{\text {th }}$ December 2019 to coincide with the entry into force of the Kampala Convention on $6^{\text {th }}$ December 2012.

Therefore, the commemoration of the $10^{\text {th }}$ anniversary of the Kampala Convention is an opportune moment to set out for the first time a view of the Kampala Convention from inside the kitchen by the author, informed by inside knowledge of having led its drafting and negotiation from 2005 to its adoption in 2009. An obvious drawback to an article of this nature is that limitations of space do not allow a rendition of the actual drafting and negotiation process and related insights into the Kampala Convention. In giving crucial insights, for example, it is not well known outside the kitchen that the drafting and negotiation of the Kampala Convention was informed primarily by the 2006 International Conference of the Great Lakes' Protocol on Protection and Assistance to Internally Displaced Persons, an instrument that was also drafted by the author.

This Protocol was in fact the first binding legal instrument on the protection of, and assistance to, internally displaced persons, albeit at sub-regional level. Behind the negotiating scenes of the African Union, the Great Lakes' Protocol had been marked out to be the default African Union treaty to protect and assist internally displaced persons. This was to provide for the possibility that negotiations of the Kampala Convention might fail, which seemed likely in light of the frequent failure by the African Union in drafting other treaties. Acclaimed as it should be, the narrative behind the adoption of the Kampala Convention is oblivious to the fact that the Convention was almost doomed to failure in the negotiating phases, and that its eventual adoption came about almost against all odds.

Ten years on, the value and contribution of the Kampala Convention to international law should be acknowledged on both scholarly and substantive terms. In terms of scholarship, the Kampala Convention has generated new academic scholarship, with at least three books written on it, ${ }^{10}$ a testimony to its entrenchment of internally displaced persons as an academic subject. A number of articles have also extolled the Kampala Convention as a model for strengthening and consolidating the normative framework for the protection of internally displaced persons. ${ }^{11}$

\footnotetext{
9"The African Union's Theme for 2019", the United Nations Refugee Agency, June 19, 2019. Available at: https://www.unhcr.org/uk/the-african-unions-theme-for-2019.html.

10 Romola Adeola, Development-Induced Displacement and Human Rights in Africa: The Kampala Convention (Routledge Contemporary Africa, eBook, 2021); Allehone Abebe, The Emerging Law of Forced Displacement in Africa: Development and Implementation of the Kampala Convention on Internally Displaced Persons (Routledge, 2017); Mehari Teddele Maru, The Kampala Convention and Its Contributions to International Law: Legal Analyses and Interpretations of the African Union Convention for the Protection and Assistance of Internally Displaced Persons (Eleven International Publishing, 2014).

${ }^{11}$ See Megan Bradley and Mike Asplet, 'Strengthened Protection for Internally Displaced Persons in Africa: The Kampala Convention Comes Into Force', American Society of International Law, 16 (36), (2012), 6; See Walter Kälin, 'Consolidating the Normative Framework for IDPs', International Journal of Refugee Law, 30(2)(2018) 314-317; Adama Dieng, 'Protecting internally displaced persons: The value of the Kampala Convention as a regional example', International Review of the Red Cross, 99(904) (2017) 263-282.
} 
It should be of great academic appreciation that the creative process of the lawmaking nature of the Kampala Convention was originally derived from primary and applied academic research. This exemplifies how academic research and knowledge should be utilised appropriately not only to deal with contemporary social problems, but also to offer concrete ways to address them in order to shape the well-being in the world. To this end, the Kampala Convention has engendered further academic research, enriched academic writing, and deepened our understanding of the role of international law in relation to internally displaced persons as never before. As the Secretary Generals' commemorative statement shows, the Kampala Convention has crystallised momentum beyond its regional scope.

In terms of substantive content, the Kampala Convention was devised to be a modern futuristic treaty. A key question asked at the outset of the first Expert Group meeting to deliberate on the drafting of the Convention in 2005 was how would the situation of internal displacement in Africa be like in 50 years' time and beyond, and what type of legal instruments would be necessary to address it beyond this timeline? A counter argument, which did not prevail, was that there would be no internally displaced persons in Africa in 50 years' time. This argument was defeated on the back of Africa's experience with the 1969 Organisation of African Unity Convention Governing the Specific Aspects of the Refugee Problem in Africa, which was adopted based on the misperception that refugee outflows in Africa would end after the independence of African states from colonialism. This turned out to not be the case. A similar analogy was forecast with respect to the continuation of the phenomenon of internal displacement in Africa in the future.

In sketching out the central argument on the modernisation by the Kampala Convention of the international legal regime for protecting and assisting internally displaced persons, this article begins with a short background to the Kampala Convention, outlines the context of the obligations as set in the scope of the Kampala Convention, including state responsibility for protection and assistance, measures of special protection, obligations relating to humanitarian and other actors, disasters and climate change, accountability of state and non-state actors, provision of durable solutions and compensation, the consultation and participation of internally displaced persons, and the domestication of the Kampala Convention to bring about its implementation. While the Kampala Convention is a momentous measure that provides a solid framework for protecting and assisting those affected by displacement, including durable solutions for them, its real gains remain to be delivered effectively.

\section{BACKGROUND}

The Kampala Convention was adopted in 2009 after four years of consultations, drafting, and negotiations, under the auspices of the African Union. This process arose out of respect for the decision of the Executive Council of the African Union, in July 2004, that a separate 
and appropriate regional framework should be developed in Africa to adequately protect and assist internally displaced persons and to support durable solutions. ${ }^{12}$

The decision of the African Union to elaborate a legal framework to protect and assist internally displaced persons clearly represented the will and determination of African States to address holistically the problem of internal displacement on the continent of Africa. In broaching this issue, it is also true that the African Union sought to redress the imbalance created by the fact that 1969 Organisation of African Unity Convention Governing the Specific Aspects of Refugee Problems in Africa that provides a legal framework relating to refugees while there was no comparable legal framework in place to provide for the protection of internally displaced persons, despite the gravity of the situation of internal displacement in Africa.

Although the political will and commitment to adopt a Convention to protect and assist internally displaced persons in Africa was loudly applauded, the process of negotiating it was tedious and came close to collapse had it not been rescued by displacement affected States. These States had a vital interest to support the Convention in view of their own experiences and desire to put in place a legal framework to protect and assist internally displaced persons in Africa.

Indeed, the entry into force of the Kampala Convention did come about merely as a gesture of goodwill; it happened due to concerted promotion to ratify it. At the sixteenth session of the United Nations Human Rights Council, the author as United Nations Special Rapporteur on the human rights of internally displaced persons 2010-2016, presented to the Human Rights Council his strategy to actively promote the ratification of the Kampala Convention by African States and to continue to provide assistance in putting in place policies and legislative frameworks to ensure its implementation at the national level. ${ }^{13}$

At his instigation, the African Union Commission spearheaded the promotion of the process of ratifying the Convention throughout Africa and devised a plan of action for the implementation of the Convention that the State Members of the African Union adopted. Speaking from inside the kitchen, it is these specific efforts that enabled the Kampala Convention to come into force within three years of its adoption, and as noted already, a record time in comparison to the period of time that treaties adopted by the African Union generally take to come into force.

\section{CONTEXT}

The context of the legal framework of the Kampala Convention has sometimes been portrayed erroneously as a human rights treaty that merely incorporates the 1998 Guiding Principles on Internal Displacement. It is undeniable that the Guiding Principles were an essential step in establishing a soft law framework on internal displacement; these

12 African Union Executive Council Decisions EX.CL/Dec.129 (V) and EX.CL/127 (V), 2004.

$13 \mathrm{~A} / \mathrm{HRC} / 16 / 43$, para. 58. 
principles were extrapolated from existing hard law, and clarified international standards for protecting and assisting internally displaced persons within international human rights law, international humanitarian law, and international refugee law by analogical extension.

In practice international, regional and sub regional organizations increasingly acknowledged, relied on, and applied the Guiding Principles, ${ }^{14}$ while States increasingly committed to adhering to the Guiding Principles and to incorporating them into their domestic legal frameworks. ${ }^{15}$ In 2004 the Summit of the Heads of States sitting at the United Nations endorsed the Guiding Principles as the recognised international normative framework for protecting and assisting internally displaced persons. In commemoration of the $20^{\text {th }}$ anniversary of the Guiding Principles in 2018, the GP20 project engineered by the United Nations High Commissioner for Refugees (UNHCR) pioneered the implementation of the Guiding Principles into domestic law.

All of these were, and remain, significantly important developments to the international legal regime concerning protection and assistance to internally displaced persons. However, the inside view is that the drive for the making of the Kampala Convention had its genesis not from the Guiding Principles but from the International Conference on the Great Lakes, which was the first to adopt a legally binding treaty, albeit of limited scope, in the form of the 2006 Protocol on the Protection and Assistance to Internally Displaced Persons. Between 2003 and 2006, the African Union observed the drafting and negotiation by the then 11 States of the International Conference of the Great Lakes Region.

Supported by the author, the Conference drafted, negotiated and adopted, a legally binding Pact on Security, Stability and Development in the Great Lakes Region ${ }^{16}$, which entered into force in June 2008. The Pact formerly comprised 10 separate Protocols, including the Protocol on the Protection and Assistance to Internally Displaced Persons and the Protocol on the Property Rights of Returning Persons. The Protocol on Protection and Assistance to Internally Displaced Persons obliged Member States of the International Conference of the Great Lakes Region to adopt the Guiding Principles as a legally binding instrument and to enact national legislation to domesticate and implement them within national legal systems, and to ensure the effective participation of internally displaced persons in developing such legislation.

The Great Lakes Protocol on Protection and Assistance to Internally Displaced Persons inspired the crystallisation of the Kampala Convention to not only protect and assist internally displaced persons, but also to support regional efforts in Africa to achieve peace, security and development. ${ }^{17}$ Indeed, when the negotiation of the Kampala Convention stumbled, the Protocol on Protection and Assistance to Internally Displaced Persons was positioned to be the default African Union Convention on internal displacement. However, African Union practice would not have permitted the Guiding Principles to be annexed in the way that the

\footnotetext{
14 See Organization of American States' resolution 2667 of 7 June 2011 (AG/RES. 2665 (XLI-O/11). See also Council of Europe's recommendation Rec (2006)6 of 5 April 2006, available at: https://rm.coe.int/16806b5aaf. ${ }_{15} \mathrm{~A} / 67 / 289$, paras. 34 and 40 .

${ }^{16}$ Chaloka Beyani, 'Introductory Note on the Pact on Security, Stability and Development in the Great Lakes Region 2006', International Legal Materials 46 (2007) 173-75. After gaining its independence on 9 July 2011, South Sudan became the $12^{\text {th }}$ Member State of the International Conference on the Great Lakes and ratified the Pact on Security, Stability and Development in the Great Lakes Region in 2012.

${ }^{17}$ Chaloka Beyani, "The Elaboration of a Legal Framework for the Protection of Internally Displaced Persons in Africa", Journal of African Law, (50)(2), 2006, pp.187-197.
} 
Protocol on Protection and Assistance to Internally Displaced Persons had done. If the negotiation of the Kampala Convention itself had collapsed, as seemed likely, therein lay the dilemma of how to adopt the Protocol as an African Union Convention, since it had spurred momentum towards the adoption of the Kampala Convention. It is for this reason that the Kampala Convention directly incorporates the Guiding Principles on Internal Displacement. 18

\section{SCOPE OF THE CONVENTION}

Unlike the Guiding Principles that are formulated from the perspective of the human rights of internally displaced persons, the Kampala Convention is grounded on state responsibility and the responsibilities of other entities and actors. This is the key modernising aspect of the Kampala Convention that transcends the Guiding Principles and is drawn on the author's early approach to this subject. ${ }^{19}$ The narrative behind state responsibility has now metamorphosed into a 'whole of Government approach' to protecting and assisting internally displaced persons. Nevertheless, the Kampala Convention still reinforces the Guiding Principles' pioneering combined framework of international human rights law, international humanitarian law, and the analogical application of international refugee law.

\section{MULTIFACETED OBLIGATIONS}

Drafted as a modern treaty, the Kampala Convention creates state centric obligations based on state responsibility, alongside obligations of non-state actors, including their accountability for displacement. In its Article 2(d) for example, the Convention provides for the obligations and responsibilities of state parties, while also specifying obligations concerning the accountability of armed opposition groups, and non-state actors such as private companies, private security companies, humanitarian agencies, civil society organizations, international organisations, internally displaced persons, and displacement affected communities. Article 3 of the Kampala Convention recognizes the general obligation of States to refrain from, prohibit and prevent arbitrary displacement of populations; the obligation to prevent some of the underlying causes of internal displacement, such as political, social, cultural and economic exclusion and marginalization; ensures respect for and protection of the human rights of internally displaced persons, and international humanitarian law.

Furthermore, the Kampala Convention modernises the legal regime relating to internally displaced persons under the Guiding Principles by identifying, non-exhaustively, a wide

18 E/CN.4/1998/53/Add.2, annex.

${ }^{19}$ Chaloka Beyani, 'State Responsibility for the Prevention and Resolution of Forced Population Displacements in International Law', International Journal of Refugee Law, 7(1995) 130-147. See further, Francis M. Deng, 'Frontiers of Sovereignty: a Framework of Protection, Assistance, and Development for the Internally Displaced', Leiden Journal of International Law, 8(2) (1995) 249-286. 
range of causes of arbitrary displacement, demonstrating that this is not only caused by armed conflict. ${ }^{20}$ Therefore, the Kampala Convention has made important advances in enumerating in Art 4(4) an expansive list of acts that may cause arbitrary displacement, thereby going further than those set out in the Guiding Principles.

Besides armed conflict and situations of generalized violence or human rights violations, the Kampala Convention obliges State parties to protect all persons against policies of racial or other discrimination aimed at or resulting in altering the ethnic, religious or racial composition of the population; displacement due to harmful practices; ${ }^{21}$ and forced evacuations in situations of disasters or other scenarios where evacuation is not required by health or safety considerations of those affected. The injunction against the use of "healthy and safety" reasons to justify displacement that is fundamentally arbitrary is an important safeguard established by the Kampala Convention.

Similarly, the Kampala Convention devotes Article 10 to circumscribing internal displacement caused by development projects carried out by public and private actors, which was one of the most contentious issues in the negotiation of the Kampala Convention. The obligations underlying development related displacement under Article 10 were eventually accepted as a template for project financing in situations where development projects would lead to displacement.

In this and other scenarios, a clear objective was to prohibit all forms of arbitrary displacement, in all circumstances, including forced evictions. In this regard, Article 4 of the Kampala Convention provides a "catch-all" by articulating the obligations of State Parties to prevent arbitrary displacement caused by an "act, event, factor or phenomenon of comparable gravity to all of the above" that is not justified under international law, including human rights and international humanitarian law.

\section{ACCOUNTABILITY}

Accountability for acts of displacement is one of the most important and yet vexatious aspect of protecting internally displaced persons. It goes without saying that the ambition of the Kampala Convention to establish the accountability of States and non-State actors for displacement was the hottest spot in the kitchen as it was challenged serially throughout its negotiation phase. Ultimately the modernisation project of the Kampala Convention triumphed in unusually combining the responsibilities of States and private actors in a treaty that is usually designed for States. In article $3(1)(\mathrm{g})(\mathrm{h})(\mathrm{i})$, the Kampala Convention obliges States to ensure individual criminal responsibility for acts of arbitrary displacement in accordance with applicable domestic and international criminal law as well as for non-

\footnotetext{
20 Megan Bradley and Mike Asplet, "Strengthened Protection for Internally Displaced Persons in Africa: The Kampala Convention Comes Into Force”, above, note 10.

${ }^{21}$ Under article 1 (j) of the Kampala Convention, "harmful practices" denotes all behaviour, attitudes and/or practices that negatively affect the fundamental rights of persons, such as, but not limited to, their right to life, health, dignity, education or mental and physical integrity. For example, female genital mutilation or cutting is considered a form of harmful practice.
} 
State entities complicit in such displacement, including multinational companies or private security organizations, and those involved in the exploitation of economic and natural resources leading to displacement.

As for the main obligations of States, the general basis for state responsibility descends principally from Article 9 of the Kampala Convention. According to this provision, States are obliged to protect the human rights of internally displaced persons during displacement, regardless of the cause of their displacement, and to refrain from and prevent the following acts: discrimination, including displacement based on discrimination itself; genocide, crimes against humanity, war crimes and other violations of international law committed against displaced persons; forms of cruel, inhuman or degrading treatment or punishment, including arbitrary killing, summary execution, arbitrary detention, abduction and enforced disappearance or torture; sexual and gender-based violence, including rape, harmful practices, the recruitment of children and their use in hostilities, forced labour, human trafficking, smuggling; and starvation. States moreover have the obligation to guarantee the safety, security and dignity of internally displaced persons, to respect and ensure their freedom of movement and choice of residence, and to protect them against forcible return or resettlement to areas where their life, safety, liberty and/or health would be at risk.

Obligations relating to the African Union under the Kampala Convention establish a further layer of responsibility by linking its framework of protection and assistance to internally displaced persons to the right of the African Union in article 4 (h) of the 200 African Union Constitutive Act to intervene in a Member State in respect of grave circumstances, namely, war crimes, genocide and crimes against humanity. This prospect, though seemingly unrealistic at present, does however raise the horizon of the modernisation of the legal regime relating to internally displaced persons by explicitly recognising the necessity to resort to intervention in grave situations affecting internally displaced persons.

Beyond state responsibility, a most significant and far reaching aspect of the Kampala Convention establishes the accountability of members of dissident armed groups or other organised armed groups that are distinct from the armed forces of the State for criminal acts committed by them in causing displacement. ${ }^{22}$ Seeking to combat impunity, the Kampala Convention notably holds members of armed groups accountable for human rights violations against internally displaced persons, stipulating that members of armed groups are to be held criminally responsible for acts that violate the rights of displaced persons under international law and national law. Article 7 of the Kampala Convention lists a series of actions that armed groups are prohibited from carrying out, in accordance with international law.

In particular, Article 7 (4) of the Kampala Convention provides that States must hold members of armed groups criminally responsible for acts that violate the human rights of internally displaced persons and contrary to international humanitarian law. According to

22 Under Article 1(n) of the Kampala Convention, non-state actors are defined as private actors who are not public officials of the State or whose acts cannot be officially attributed to it, and Article 1(e) defines armed groups are defined as dissident armed forces or other organized armed groups that are distinct from the armed forces of the State. 
Article 5 (11), such emphasis on the obligations of non-State actors and members of armed groups does not take away the primary responsibility of State Parties, which are required to take measures aimed at ensuring that armed groups act in conformity with the obligations governing the accountability of States under article 7 .

These provisions of the Kampala Convention on armed groups were contested throughout the negotiation of the Kampala Convention, a contestation which went all the way to the Summit of the Heads of State that eventually adopted by the Convention. Their inclusion in the Kampala Convention at the insistence of displacement affected States marked the hall mark of the Kampala Convention as a modernising treaty that combines the responsibilities of States, and those of armed groups in the field of internal displacement.

There are also instances of special protection obligations under the Kampala Convention, which relate to special needs and pastoralists. Article 9 (2) of the Kampala Convention requires States to provide special protection and assistance to internally displaced persons with special needs, including separated and unaccompanied children, female heads of household, expectant mothers, mothers with young children, persons with disabilities and older persons, and to take measures for family tracing and reunification. Special protection for pastoralists arises from the consideration that pastoralism in Africa is characterized by a high reliance on livestock as a source of economic and social wellbeing and depends on various types of strategic mobility to secure access to water and grazing resources in areas with a high degree of rainfall variability. Pastoralism is found in all regions of Africa, where, in some regions, it is the dominant livelihood. In 2010, pastoral areas were known to occupy some 40 per cent of African land mass. ${ }^{23}$ Contrary to assumptions and despite their tradition as nomads, pastoralists do suffer from arbitrary displacement. Displacement of pastoralists is closely linked to the loss of livestock and of access to markets. ${ }^{24}$

All causes of internal displacement identified in the Kampala Convention can be causes of forcible internal displacement for pastoralists. ${ }^{25}$ Therefore, like the Guiding Principles on Internal Displacement and the Protocol on the Protection and Assistance to Internally Displaced Persons, the Kampala Convention pays particular attention Article 4 (5) to this widespread phenomenon, obliging State Parties to endeavour to protect communities with special attachment to and dependency on land owing to their particular culture and spiritual values. In the scope of the provisions on development related displacement, any projects with an impact on the right of pastoralists to use land have to be justified by compelling and overriding public interest. The threshold that public interest must reach is therefore higher owing to the ancestral and spiritual attachment that pastoralists have with the land. ${ }^{26}$

23 "Policy framework for pastoralism in Africa: Securing, protecting and improving the lives, livelihoods and rights of pastoralist communities", African Union, October 2010. Available at: https://au.int/sites/default/files/documents/30240-doc-policy framework for pastoralism.pdf, p. 1.

24 A/HRC/19/54/Add.2, para. 13.

25 "On the margin: Kenya's pastoralists", Internal Displacement Monitoring Centre, March 2014. Available at: www.internal-displacement.org/publications/2014/on-the-margin-kenyas-pastoralists

26 "The Kampala Convention, One year On: Progress and Prospects", Internal Displacement Monitoring Centre, December 2013, p. 27. Available at: https://www.internal-displacement.org/publications/the-kampalaconvention-one-year-on-progress-and-prospects 


\section{DISASTERS AND CLIMATE CHANGE}

The Kampala Convention was the first treaty to express obligations combining the effect of disasters and climate change with specific reference to internal displacement, before the 2011 Cancun agreements recognised the category of climate change induced displacement. ${ }^{27}$ On the one hand, Article 5(4) of the Kampala Convention obliges State parties to take measures to protect and assist persons internally displaced due to disasters, including climate change. On the other hand, it obliges State Parties in Article 4(2) to prevent and mitigate the effects of disasters, including by establishing early warning systems and implementing disaster risk reduction strategies, emergency and disaster preparedness and management measures in areas at risk.

The special attention drawn to disasters and climate change in the Kampala Convention is reinforced by the fact that in 2012 alone, an estimated 7.7 million persons were displaced in the wake of natural disasters in countries that have signed or ratified the Kampala Convention. ${ }^{28}$ From an inside view, it is however necessary to point out that provisions of the Convention on disasters and climate change drew on the Inter-Agency Standing Committee's Operational Guidelines on the Protection of Persons in Situations of Natural Disasters, ${ }^{29}$ and the African Union's regional disaster risk reduction strategy programme of action 2006-2015. The latter was aimed towards the attainment of sustainable development and poverty eradication through a substantial reduction in the social, economic and environmental impact of disasters, including risks associated with climate change. ${ }^{30}$

\section{OBLIGATIONS TO PROVIDE HUMANITARIAN ASSISTANCE}

The Kampala Convention makes clear that States have the primary responsibility for providing protection and assistance to internally displaced persons. Its modernisation effect is to integrate separate obligations on humanitarian assistance under the Guiding Principles into state responsibility for protecting internally displaced persons. Specifically, Article 9(2) of the Kampala Convention, obliges State Parties to provide internally displaced persons, to the fullest extent possible and with the least possible delay, with food, water, shelter, health services, sanitation, education and any other necessary social services. Given the important ways in which displacement can affect the resources and coping capacities of communities affected by displacement, including host and return communities, States are also required, where appropriate, to extend their assistance to local and host communities. Furthermore, States are to take measures to monitor and evaluate the effectiveness and impact of humanitarian assistance provided to internally displaced

${ }^{27}$ FCCC/CP/2010/7/Add.1, para.14(f).

28 See fn. 27, p. 21.

29 "IASC Operational Guidelines on the protection of persons in situations of natural disasters", Inter-Agency Standing Committee, January 2011.

Available at: https://www.ohchr.org/Documents/Issues/IDPersons/OperationalGuidelines IDP.pdf

30 Ibid. 
persons, in accordance with relevant standards of practice, including those of the Sphere Project.

When available resources are inadequate, however, Article 5 (6) of the Kampala Convention requires State parties to cooperate in seeking the assistance of international organizations and humanitarian agencies, civil society organizations and other relevant actors. In this regard, State Parties should take the steps necessary to ensure effective and unimpeded access by humanitarian organizations and other entities that are in a better position to provide internally displaced persons with protection and assistance.

The Kampala Convention further elaborates on this issue in its Article 6, which addresses the legal obligations for international organizations and humanitarian agencies. Article 6 requires such entities to discharge their mandates in conformity with international law and the laws of the countries in which they operate; to respect the rights of such persons in accordance with the law; and to discharge their mandates in full respect of the principles of well-known principles of humanity, neutrality, impartiality, based on the independence of these organisations.

\section{OBLIGATIONS RELATING TO DURABLE SOLUTIONS AND COMPENSATION}

Durable solutions are sustainable solutions to the problem of internal displacement. The Kampala Convention reinforces the Guiding Principles' approach to durable solutions. Article 11 of the Kampala Convention obliges State Parties to promote and create satisfactory conditions for attaining durable solutions in safety and in dignity, including voluntary and sustainable return to their homes or places of habitual residence, local integration in places of displacement, or relocation elsewhere within the country. States are obliged to consult internally displaced persons on their options for securing durable solutions to displacement to enable them to make a free and informed choice on return, local integration or relocation, and for ensuring their participation in durable solutions. 31 However, Article 11(3) links protection and assistance to the implementation of durable solutions, which is effectively a new approach to integrating durable solutions into protection and assistance at the outset throughout till long term reconstruction.

In Article 12, the Kampala Convention introduces a novel feature which obliges State Parties to provide persons affected by displacement with effective remedies. The purview of this obligation is sometimes misunderstood as entailing State Parties to provide compensation and reparation to internally displaced persons on the face of the provisions in Article 12 of the Kampala Convention. While it is true that that may be the ultimate objective, however, the corpus of the obligation is actually spelt out in Article 12(2), and that is 'to establish an effective legal framework to provide just and fair compensation and

31 "Framework on Durable Solutions for Internally Displaced Persons", Inter-Agency Standing Committee, 2010. Available at: https://docs.unocha.org/sites/dms/Documents/IASC $\% 20$ Framework $\% 20$ DS $\% 20$ for $\% 20$ IDPs.pdf. 
other forms of reparations to internally displaced persons, where appropriate, for damage incurred as a result of displacement, in accordance with international standards'.

A delicate compromise was necessary to agree this provision, deferring to States to establish such an effective legal framework, fettered by international standards. The delicate language in Article 12(2) was borne out of the experience of the negotiation of the 2006 Protocol on the Rights of Returning Persons of the International Conference on the Great Lakes, where the issue of compensation was so divisive that the participating States settled eventually on the provisions of a vague restrictive 'compensation package' to be determined exclusively on the basis of national legislation under Article 8(3) of that Protocol. The Kampala Convention has to be seen as a modification of this formula, by adding 'just and fair compensation' in accordance with international standards.

Article 11 (4) of the Kampala Convention also requires States to take measures for the resolution of property disputes and the recovery of property, including by establishing simplified property dispute resolution mechanisms for internally displaced persons; and restoring the lands of communities with a special dependency and attachment to such lands upon the return of communities and their reintegration (Art. 11 (5)). States are further obliged by Article 12(2) to establish an effective legal framework to provide displaced persons, in accordance with international standards, with just and fair compensation and other forms of reparations for damage incurred as a result of displacement, in accordance with international standards.

\section{PARTICIPATION AND CONSULTATION OF INTERNALLY DISPLACED PERSONS AND HOST COMMUNITIES}

Throughout the Kampala Convention, there is an emphasis on the obligation of State Parties to consult internally displaced persons and allow them to participate in decisions relating to their protection and assistance (for example, art. 9 (2)). This obligation extends to decisions regarding the range of durable solutions available to internally displaced persons, in order to enable them to make a free and informed decision.

States must also take measures to ensure that displaced persons who are citizens of their country of habitual residence may enjoy their civil and political rights, particularly in relation to public participation, such as the right to vote and the right to run for public office. Experience showed that where, electoral violence was a related cause of displacement, such as in Kenya and Cote d'Ivoire, public participation of internally displaced persons including their right to vote was either denied or restricted for reasons related to their displacement. The principle of participation and consultation also applies to development projects, with Article 10 (2) obliging State Parties to ensure that feasible alternatives to displacement caused by development projects are explored, with full information given to, and consultation with, persons likely to be displaced by such projects.

The Kampala Convention obliges States to take appropriate measures to take into account the protection and assistance needs of communities hosting or receiving persons 
displaced within States. The Kampala Convention is alive to the fact that such communities are significantly affected by internal displacement and are also a protecting agent, given that a great majority of internally displaced persons tend not to live in camps but rather with communities and families. ${ }^{32}$ Thus their involvement and participation in protection and assistance assessments to ensure that their needs are taken into consideration for appropriate humanitarian responses and development action to enable durable solutions. Post the Kampala Convention, this has become known as 'a whole of society approach' focused not just on internally displaced persons, but on society and different actors within it as a whole, for the purpose of attaining durable solutions for internally displaced persons in particular.

\section{MONITORING AND COMPLIANCE WITH OBJECTIVES}

The Kampala Convention was negotiated with a view to its implementation in order to be effective. To this end, monitoring and compliance mechanisms were built into it. In Article 8, the Kampala Convention identifies an important role for the African Union to support State Parties in fulfilling their obligations under the Kampala Convention. It makes imaginative provision for a Conference of State Parties (Article 14) to convene regularly under the facilitation of the African Union (Article 14.2) to monitor its implementation. State Parties are also obliged to cooperate with each other to protect and assist internally displaced persons upon the request of a concerned State Party or the Conference of State Parties itself (Article 5.2). In compliance with Article 14(2), the Conference of State Parties convened for the first time in Zimbabwe in 2017 and adopted the Harare Plan of Action for the implementation of the Convention, aimed at fulfilling the objectives of the Kampala Convention in Article 2.33

Two other mechanisms for reporting on compliance are outlined in the Kampala Convention. States must report on the measures they have taken to give effect to the Convention whenever they present their reports under Article 62 of the African Charter on Human and Peoples' Rights (Art. 14.4). State Members of the African Union that have joined the African Peer Review Mechanism must also report on such measures when they present their reports under the Mechanism in Article 14.4 of the Kampala Convention.

\section{DOMESTICATION AND IMPLEMENTATION}

In light of the patchy record of domesticating and implementing treaties in Africa, the Kampala Convention sought to rectify this state of affairs by obliging State Parties to

\footnotetext{
32 See fn. 27 , p. 21.

33 "Plan of action for the implementation of the Kampala Convention adopted by conference of states parties", African Union, April 6, 2017. Available at: https://au.int/en/pressreleases/20170406/plan-action-implementationkampala-convention-adopted-conference-states
} 
domesticate and implement it to achieve its objectives. Therefore, Article 3 (2) provides for the incorporation of States' obligations into domestic law by enacting or amending relevant legislation on the protection of and assistance to displaced persons in conformity with their obligations under international law. By the same provision, State parties must take other measures, such as national or local policies, and create strategies regarding internally displaced persons whilst also accounting for the needs of receiving or host communities.

The merit of these obligations underlies the experience that an effective response to internal displacement almost always requires a solid enabling legislative and policy framework. Existing laws can hinder the ability of internally displaced persons to realize their rights or might not ensure that the specific assistance and protection needs of displaced persons are met. ${ }^{34} \mathrm{~A}$ comprehensive national law aimed at implementing the Kampala Convention must at the very least incorporate its standards on internal displacement and address all forms of internal displacement holistically irrespective of the causes. Such a holistic perspective ranges from the prevention of arbitrary displacement, to integrating protection and assistance, to the achievement of durable solutions.

With hindsight, the Kampala Convention was adopted against the backdrop of national efforts to develop laws and policies on internal displacement in Africa, which predated it, but aligned to the Guiding Principles. Five African States to have developed laws or policies on internally displaced persons based on the Guiding Principles are Angola (2000), Burundi (2001), Sierra Leone (2002), Uganda (2004), and the Sudan (2009). Of these, Angola, Sierra Leone, and Uganda subsequently ratified the Kampala Convention and are obliged to incorporate it.

While the laws or policies developed by these States are a positive development, in reality they vary in scope and in the extent of their protection and assistance offered to internally displaced persons. For example, not all the laws or policies include even an appropriate definition of an internally displaced person ${ }^{35}$ or clearly identify institutional responsibilities regarding one. In addition, some address only a particular cause or stage of displacement, such as conflict or return, while others focus only on particular rights.

Distinct from these, Kenya in 2012 set the baseline for emerging state practice on the domestication of international obligations concerning internally displaced persons by incorporating the Great Lakes Protocol on Protection and Assistance to Internally Displaced Persons and absorbing the Guiding Principles. The Prevention, Protection and Assistance to Internally Displaced Persons and Affected Communities Act (2012) by Kenya absorbed the Guiding Principles and further contemplated the incorporation of the Kampala Convention thereby effectively speaking to it.

Ten years after its adoption and eight years after it entered into force, the domestication of the Kampala Convention, let alone its implementation, has been pedestrian.

34 "Protecting Internally Displaced Persons: A Manual for Law and Policymakers", Brookings-Bern Project on Internal Displacement, October 2008, p. 27. Available at: https://www.brookings.edu/research/protecting-internallydisplaced-persons-a-manual-for-law-and-policymakers/

35 According to the Guiding Principles on Internal Displacement and the Kampala Convention, the fact of being an internally displaced person does not imply any legal status. An appropriate definition of an internally displaced person should encompass all causes of displacement. 
Only Niger (2019) has incorporated it. ${ }^{36}$ Ethiopia and South Sudan ratified the Kampala Convention in 2019 and 2018 respectively and they both have, with the guidance of the author, prepared comprehensive draft legislation on internally displaced persons to implement the Kampala Convention. Somalia recently ratified the Kampala Convention on 26 November 2019 and is poised to domesticate it in 2020.

The question arises of why ratification of the Kampala Convention has progressed, and yet its domestication by these ratifying States remains patchy. Has the political will to domesticate the Kampala Convention waned? Here the author argues that the political will behind the Kampala Convention has not diminished, having felt the pulse of politics as the United Nations Special Rapporteur on the human rights of internally displaced persons from 2010-2016 when promoting the ratification of the Kampala Convention, and also in leading efforts to implement it. He also tested the waters of political commitment as keynote speaker at the official events held by the African Union to mark the declaration of 2019 as the year of refugees, returnees, and internally displaced persons, including the $10^{\text {th }}$ anniversary event held on $6^{\text {th }}$ December 2019 in Kampala.

In engaging with African States on the issue of domestication, two main difficulties have become apparent. One lies in the difficulty faced by African States in applying the Kampala Convention and its modern aspects that combine State responsibility, the responsibility of international organisations, including the African Union, and those of non-state actors, particularly armed groups, in constitutionalised legal systems. Another relates to the complexity of both the process and the technical expertise required to prepare appropriate substantive legislation to incorporate or domesticate the Kampala Convention. Such implementing legislation has to provide as its aim a national framework to protect and alleviate the suffering of a substantial segment of a population of a State that, by virtue of being displaced from their homes or places of habitual residence within the State, has fallen outside the protective scope of existing laws and administrative structures.

It is for this reason that the Manual for Law and Policymakers was prepared by the United Nations mandate on the protection of the human rights of internally displaced persons and the Brookings Project to guide state practice on developing domestic legislation and policies addressing internal displacement. ${ }^{37}$ Other documents providing similar guidance include a manual on the law or policy development process, and the Handbook for Parliamentarians on internal displacement. ${ }^{38}$ These manuals distil years of good state practices and lessons learned to aid the drafting of laws and policies that address internal displacement as well as in amending existing laws and policies to protect and assist internally displaced persons, and to attain durable solutions for them.

Emerging state practice shows that the development of a national law or policy on internally displaced persons is a consultative process encompassing several stages,

36 Niger: Loi $n^{\circ}$ 2018-74 du 10 décembre 2018 relative à la protection et à l'assistance aux personnes déplacées internes [Niger], 10 December 2018. Available at: https://www.refworld.org/docid/5ce404914.html

37 See fn. 33 above.

38 "International Parliamentary Union, Handbook: Internally Displaced Persons: Responsibility and Action", International Parliamentary Union and UNHCR, 2013.

Available at: https://www.ipu.org/resources/publications/handbooks/2016-07/handbook-internaldisplacement-responsibility-and-action 
including the initiation, preparation, organization, validation, adoption and implementation of the instrument. ${ }^{39}$ While each State party will have its own processes for developing national laws and policies on different issues, the consultative process indicated above highlights emerging state practice on the processes of domesticating the Kampala Convention in Africa. As noted already, although Kenya is not a party to the Kampala Convention, the processes that she adopted to develop a national law and policy on internal displacement ${ }^{40}$ stand out as a baseline of good state practice that has been improved upon by Ethiopia and South Sudan. These are best examples of state practice that should be built upon to guide the domestication of the Kampala Convention under the aegis of the African Union.

\section{CONCLUSION}

This article set out to excavate a view from the kitchen on the Kampala Convention's modernisation of the international legal regime for internally displaced persons, which otherwise mainly revolves around the Guiding Principles on Internal Displacement.

There is no doubt that the Kampala Convention represents a significant advance in setting standards for binding obligations to enhance the protection and assistance of internally displaced persons as well as in achieving durable solutions. While the Kampala Convention has a regional normative base in Africa, the obligations that it sets are international in character. As the first Convention of its type, the international commemoration of its $10^{\text {th }}$ anniversary demonstrates a recognition of its wider international ramifications regarding the protection and assistance of internally displaced persons.

The pitch of the Kampala Convention on state responsibility to protect and assist and find durable solutions for internally displaced persons in a binding legal framework that also establishes obligations for the African Union, international organisations, and civil society, and other non-state actors (such as armed opposition groups) are the main unique modernising characteristics of the Kampala Convention. In this way, the Kampala Convention shows how internal displacement should be addressed within a legally binding framework that includes broader obligations to tackle the effects of disasters and climate change on internal displacement, and to deal with the troublesome issues of development related displacement, and compensation or reparation for internally displaced persons.

However, as binding as it is, the Kampala Convention remains a regional treaty that is not a substitute for the globally recognised framework of the Guiding Principles on Internal Displacement. Much more, however, remains to be achieved to translate the

\footnotetext{
${ }^{39}$ Nina Schrepfer, 'Addressing Internal Displacement through National Laws and Policies: A plea for a promising means of protection; International Journal of Refugee Law, 24(4) (2012), 667-691.

40 "Behind the scenes. Lessons Learnt from Developing a National Policy Framework on Internal Displacement in Kenya", Danish Refugee Council and Refugee Consortium of Kenya, January 2013. Available at: http://drc.dk/fileadmin/uploads/pdf/IA PDF/Great Lakes PDF/BehindTheScenes KenyaIDPReport.pdf, p. 27.
} 
Kampala Convention into practice in order to secure concrete improvements in the protection of and assistance to internally displaced persons as well as achieving durable solutions for the benefit of both internally displaced persons and host communities. 